\title{
OAK FLOORING
}

\author{
(THIRD EDITION)
}

\section{COMMERCIAL STANDARD CS56-49}

[Supersedes CS56-41]

Effective Date for New Production From February 25, 1949

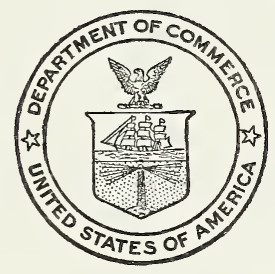

\section{A RECORDED VOLUNTARY STANDARD \\ OF THE TRADE}

\section{UNITED STATES DEPARTMENT OF COMMERCE}

CHARLES SAWYER, Secretary 


\section{COMMODITY STANDARDS}

Simplified Practice Recommendations and Commercial Standards are developed by manufacturers, distributors, and users in cooperation with the Commodity Standards Division of the National Bureau of Standards. The purpose of Simplified Practice Recommendations is to eliminate avoidable waste through the establishment of standards of practice for stock sizes and varieties of specific commodities that currently are in general production and demand. The purpose of Commercial Standards is to establish standard methods of test, rating, certification, and labeling of commodities, and to provide uniform bases for fair competition.

The adoption and use of a Simplified Practice Recommendation or Commercial Standard is voluntary. However, when reference to a Commercial Standard is made in contracts, labels, invoices, or advertising literature, the provisions of the standard are enforceable through usual legal channels as a part of the sales contract.

A Simplified Practice Recommendation or Commercial Standard originates with the proponent industry. The sponsors may be manufacturers, distributors, or users of the specific product. One of these three elements of industry submits to the Commodity Standards Division the necessary data to be used as the basis for developing a standard of practice. The Division, by means of assembled conferences or letter referenda, or both, assists the sponsor group in arriving at a tentative standard of practice and thereafter refers it to the other elements of the same industry for approval or for constructive criticism that will be helpful in making any necessary adjustments. The regular procedure of the Division assures continuous servicing of each effective Simplified Practice Recommendation and Commercial Standard, through review and revision, whenever, in the opinion of the industry, changing conditions warrant such action. Simplified Practice Recommendations and Commercial Standards are printed and made available by the Department of Commerce through the Government Printing Office.

\section{COMMERCIAL STANDARD FOR OAK FLOORING}

On December 12, 1935, the National Oak Flooring Manufacturers' Association requested that its grading rules be submitted to manufacturers, distributors, and users for approval as a commercial standard for white- and red-oak flooring. These grading rules were accepted by the trade and approved for promulgation as Commercial Standard CS56-36, Oak Flooring. This standard was revised in 1941.

A second revision, submitted by the National Oak Flooring Manufacturers' Association and approved by the standing committee, was circulated on September 30, 1948, to the trade for written acceptance. Those concerned have since accepted and approved the revised standard as shown herein.

Project Manager: J. W. Medley, Commodity Standards Division, National Bureau of Standards.

Technical Adviser: V. B. Phelan, Building Technology Division, National Bureau of Standards. 


\title{
OAK FLOORING
}

\author{
(THIRD EDITION)
}

\section{PURPOSE}

1. This standard for white-oak and red-oak flooring is a basis for common understanding between manufacturers, distributors, and users of this product. By its general acceptance, use, and certification by labels, it is hoped to increase interest in the manufacture, sale, and use of oak flooring manufactured to standard grades, to the mutual advantage of all concerned.

2. The service and satisfaction afforded by oak flooring, and, consequently, the success of the industry, depend on the use of universally recognized grades, and, therefore, the following commercial standard is provided for guidance in the manufacture, sale, and use of this product.

\section{SCOPE}

3. This standard provides minimum specifications for three grades of quarter-sawed and four grades of plain-sawed white-oak and redoak flooring. It covers standard dimensions for length, width, and thickness of tongued-and-grooved and square-edged strip flooring. It also covers defects, bundling, inspection, and a method of certifying compliance with the standard.

\section{GENERAL REQUIREMENTS}

4. All commercial standard oak flooring, except square-edged strips, shall be tongued, grooved, and end-matched in accordance with the standard dimensions shown in figures 1,2 , and 3 . It shall be well manufactured and properly kiln-dried, and it shall comply with the specifications given herein.

\section{DETAIL REQUIREMENTS}

\section{QUARTER-SAWED GRADES}

5. Clear.-The face shall be practically free of defects, except that $3 / 8$ inch of bright sapwood will be permitted. The question of color shall not be considered. ${ }^{1}$ Bundles shall be 2 feet and up in length, not to exceed 25 percent under 4 feet. Average length, 41/2 feet.

1 This applies to standard grades. Flooring separated for color can be obtained as a special by adding color requirements to the specifications. 
6. Sap clear.-The face shall be practically free of defects, but unlimited bright sapwood will be permitted. The question of color shall not be considered. ${ }^{2}$ Bundles shall be 2 feet and up in length, not to exceed 25 percent under 4 feet. Average length, 41/2 feet.

7. Select.-The face may contain sapwood, and will admit pinworm holes, streaks, slight imperfections in working, or a small tight knot, not to exceed one to every 3 feet in length. Bundles shall be 2 feet and up in length. Average length, 4 feet.

\section{PLAIN-SAWED GRADES}

8. Clear.-The face shall be practically free of defects, except that $3 / 8$ inch of bright sapwood will be permitted. The question of color shall not be considered. ${ }^{3}$ Bundles shall be 2 feet and up in length, not to exceed 25 percent under 4 feet. Average length, $4 \frac{1}{2}$ feet.

9. Select.-The face may contain sapwood and will admit pinworm holes, streaks, slight imperfections in working, or a small tight knot, not to exceed one to every 3 feet in length. Bundles shall be 2 feet and up in length. Average length, 4 feet.

10. No. 1 Common.-This grade shall be of such nature as to enable the laying of a sound floor without cutting. Bundles shall be 2 feet and up in length. Average length, 3 feet.

11. No. 2 Common.-This grade may contain defects of any character, but it shall be of such nature as to enable the laying of a serviceable floor. Bundles shall be 1//4 feet and up in length. Average length, $2 \frac{1}{2}$ feet.
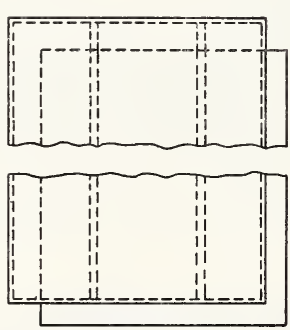

TOP VIEW
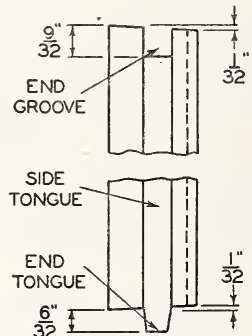

SIDE VIEW

SHOWING END-MATCHED CONDITION
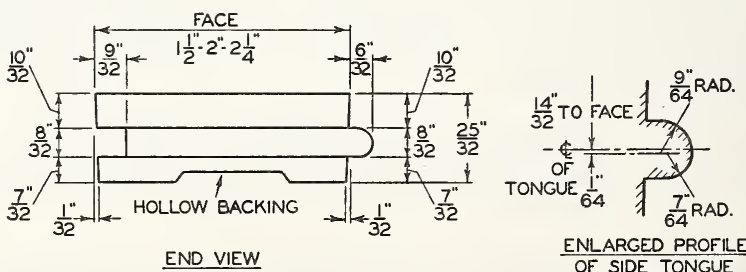

ENLARGED PROFILE

Figure 1. Dimensions for $25 / 32$-inch oak flooring.

Hollow [backing. $\quad 25 / 32$-inch flooring with 11/2-, 2-, and $21 / 4$-inch faces shall have groove on back $3 / 32$ inch deep $5 / 8,3,4$, or 1 inch wide, respectively; with sides beveled $1 / 16$ inch.

2 See footnote 1 .

3 See footnote 1 . 

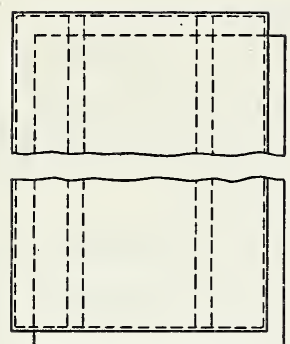

TOP VIEW

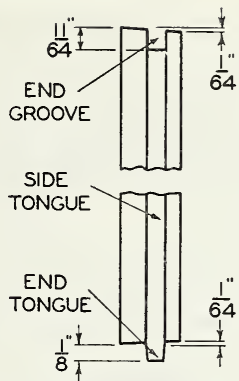

SIDE VIEW

SHOWING END-MATCHED CONDITION

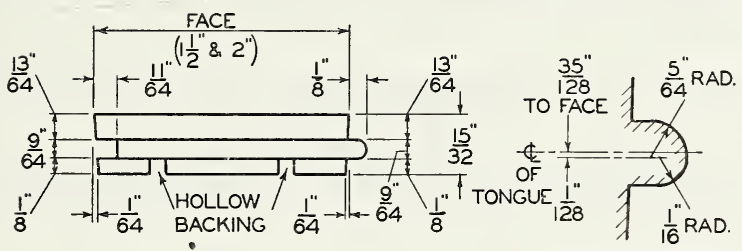

END VIEW

ENLARGED PROFILE OF SIDE TONGUE

FiguRE 2.-Dimensions for $15 / 32$-inch oak flooring.

Hollow backing. 15/32-inch flooring with 11/2-and 2-inch faces shall have two square grooves on back, each $1 / 8$ inch deep, 1/8 inch wide, and spaced 1 inch center to center.
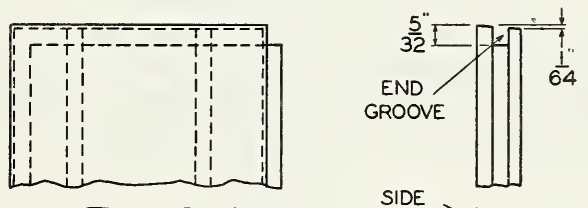

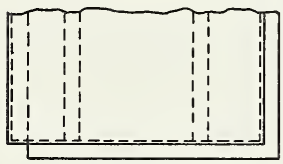

TOP VIEW

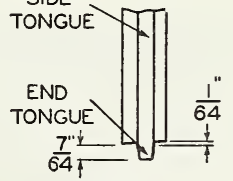

SIDE VIEW

SHOWING END-MATCHED CONDITION

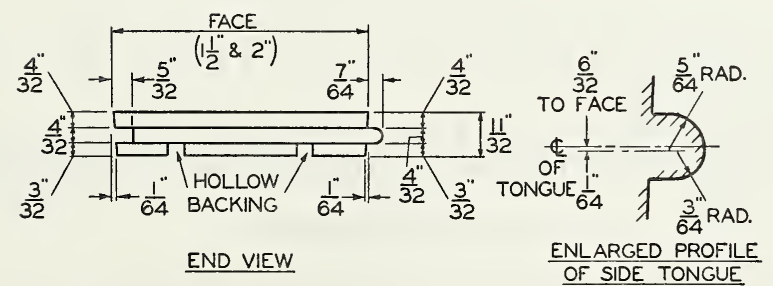

FigURe 3. Dimensions for $1 \frac{1}{3} 3$-inch oak flooring.

Hollow backing. 11/32-inch flooring with 11/2-and 2-inch faces shall have two square grooves on back, each $3 / 32$ inch deep, $3 / 32$ inch wide, and spaced $19 / 32$ inch center to center. 


\section{SQUARE-EDGED STRIP}

12. Square-edged strip flooring is manufactured in "Clear," "Select," "No. 1 Common," and "No. 2 Common" grades. The grading requirements shall be the same as those for like grades of quartersawed and plain-sawed flooring, except that bundling and lengths shall be as follows:

Clear.-Bundles shall be 2 feet and up in length. Average length, $5 \frac{1}{2}$ feet.

Select.-Bundles shall be 2 feet and up in length. Average length, $4 \frac{1}{2}$ feet.

No. 1 Common.-Bundles shall be 2 feet and up in length. Average length, $3 \frac{1}{2}$ feet.

No. 2 Common.-Bundles shall be $1 \frac{1}{4}$ feet and up in length. Average length, $2 \frac{1}{2}$ feet.

\section{STANDARD THICKNESSES AND WIDTHS}

13. Tongued, grooved, and end-matched.-Standard thicknesses and face widths for tongued, grooved, and end-matched flooring are given in table 1.

\begin{tabular}{|c|c|}
\hline \multicolumn{2}{c}{ TABLE 1. } \\
\hline Thickness (inch) & $\begin{array}{c}\text { Face width } \\
\text { (inches) }\end{array}$ \\
\hline & $\begin{array}{c}11 / 2 ; 2 ; 21 / 4 ; \\
31 / 4 . \\
11 / 2 ; 2 . \\
11 / 2 ; 2 .\end{array}$ \\
\hline $15 / 32 \ldots 2 \ldots$
\end{tabular}

14. Square-edged.-Standard thickness and face widths for squareedged flooring are given in table 2. This type is also made with rough back in ${ }^{11} / 32$-inch thickness, $1 \frac{1}{2}$ - and 2 -inch face.

TABLE 2.

\begin{tabular}{|c|c|}
\hline Thickness (inch) & Face width (inches) ${ }^{1}$ \\
\cline { 1 - 2 } $5 / 16 \ldots \ldots \ldots \ldots$ & $7 / 8 ; 1 ; 11 \frac{1}{2} ; 11 \frac{1}{4} ; 11 \frac{113 ; 11 / 2 ; 2 .}{}$ \\
\hline
\end{tabular}

1 All faces are finished $1 / 64$ inch over face.

\section{BUNDLING}

15. Oak flooring is bundled by averaging the lengths. A bundle may include pieces from 6 inches under to 6 inches over the nominal length of the bundle.

16. The percentages under 4 feet referred to in this standard apply to total footage (board feet) in any one shipment of the item.

\section{MEASUREMENT}

17. Thickness.-In computing the footage of standard oak flooring, a thickness of 1 inch shall be used.

18. Width.-Tongued-and-grooved flooring $25 / 32$ inch thick is counted as $3 / 4$ inch wider than the actual face width, and flooring $15 / 32$ inch and 
$11 / 32$ inch thick is counted as $1 / 2$ inch wider than the actual face width. Square-edged strip flooring shall be measured as of the actual face width.

19. Length.-A 3/4-inch allowance for end-matching shall be added to the face length when measuring the length of each piece of flooring.

\section{INSPECTION}

20. Utmost care is exercised in the manufacture and inspection of oak flooring, and although the most capable grading experts are employed to assure constant uniformity of standard grades, it must be remembered that they are dealing with a product of nature in which there will occasionally appear marginal pieces on which the judgment of two equally competent inspectors might differ.

21. The purchaser may refuse any shipment in which the total footage of subgrade pieces is in excess of 5 percent of the grade in question, as determined by official reinspection.

\section{REINSPECTION}

22. If the reinspection results in a difference in favor of the purchaser of more than 5 percent in feet (board measure), as shown on the invoice, then the shipper shall pay all the expenses of reinspection. If, on the other hand, the difference is only 5 percent or less in feet (board measure), the purchaser shall pay all the expenses of reinspection.

23. The quality and condition of oak flooring as it leaves the manufacturer is held to govern the reinspection.

\section{CERTIFICATION}

24. In order to assure the purchaser that he is getting oak flooring of the grade specified, producers may individually, or in concert with their trade association or inspection bureau, issue a certificate of grade with each shipment, or grade- and trade-mark each piece or bundle as conforming to this established standard.

\section{MANUFACTURERS' RECOMMENDATIONS}

25. The following information is not part of the commercial standard for oak flooring, but represents the custom of the trade and the manufacturers' recommendations, based on long experience, for maximum service from the use of oak flooring.

TABLE 3. Standard counts and weights of oak flooring

\begin{tabular}{|c|c|c|}
\hline Actual size (inches) & Counted size (inches) & $\begin{array}{c}\text { Weight per } \\
\text { M ft } \\
\text { (pounds) }\end{array}$ \\
\hline $\begin{array}{l}25 / 32 \text { by } 31 / 4 \\
25 / 32 \text { by } 21 / 4 \\
25 / 32 \text { by } 2 \\
15 / 32 \text { by } 11 / 2\end{array}$ & 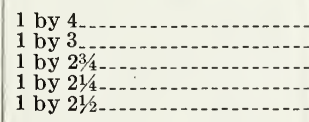 & $\begin{array}{l}2,250 \\
2,000 \\
2,000 \\
2,000 \\
1,300\end{array}$ \\
\hline $\begin{array}{l}15 / 32 \text { by } 11 / 2 \\
11 / 32 \text { by } 2 \\
11 / 32 \text { by } 11 / 2 \\
5 / 16 \text { by } 2 \\
5 / 16 \text { by } 11 / 2\end{array}$ & $\begin{array}{l}1 \text { by } 2 \\
1 \text { by } 21 / 2 \\
1 \text { by } 2 \\
\text { Face count }\end{array}$ & $\begin{array}{l}1,300 \\
1,000 \\
1,000 \\
1,200 \\
1,200\end{array}$ \\
\hline
\end{tabular}




\section{DETERMINATION OF QUANTITY REQUIRED}

26. To determine the quantity required, ascertain the square footage of the area to be covered and add thereto the following amounts:

50 percent for
$371 / 2$ percent for

The above figures are based on laying flooring straight across the room. Where there are bay windows or other projections, allowance should be made for additional flooring. It is always well to order 5 percent additional flooring to take care of floor layers' cutting and possible damage if carelessly handled.

TABLE 4. Method of determining board-foot contents of a bundle of oak flooring

\begin{tabular}{|c|c|c|}
\hline $\begin{array}{l}\text { Number of pieces per } \\
\text { bundle }\end{array}$ & Size (inches) & $\begin{array}{l}\text { Multiply } \\
\text { the length } \\
\text { of bundle } \\
\text { by- }\end{array}$ \\
\hline 12 & $25 / 32$ by $11 / 3$ & $21 / 4$ \\
\hline 12 & $25 / 32$ by $2 \ldots$ & $23 / 4$ \\
\hline $12 \ldots$ & $25 / 32$ by $21 / 4$ & 3 \\
\hline 12 & $25 / 32$ by $31 / 4$ & 4 \\
\hline $18 \ldots$ & $15 / 32$ by $11 / 2 \ldots$ & \\
\hline 18 & $15 / 32$ by $2 \ldots$ & $33 / 4$ \\
\hline 24 & $11 / 32$ by $11 / 2$ & 4 \\
\hline 24 & $11 / 32$ by 2 & 5 \\
\hline 30 & $5 / 16$ by $11 / 2 \ldots$ & $33 / 4$ \\
\hline $30 \ldots$ & $5 / 16$ by $2 \ldots$ & 5 \\
\hline
\end{tabular}

\section{ESSENTIALS OF GOOD OAK-FLOOR CONSTRUCTION}

27. It is vitally important that the following precautions be taken preliminary to the laying of oak flooring, to insure beautiful, enduring hardwood floors.

28. Defer delivery of the oak flooring until all plastering, cement, masonry work, painting, wallpapering, and interior finishing are completed and all are thoroughly dry. In no circumstances should the laying begin until such work is completed and the interior atmosphere is dry.

29. Temporary heat.-In winter weather, the building should have heat turned on before flooring is laid, to remove dampness existing in the cold atmosphere. In summer months, in certain parts of the country where there is excessive moisture, buildings of importance usually have some heat turned on before, during, and after the laying of the oak flooring, in order to remove excess moisture from the interior atmosphere. In such conditions it is best to have the bundles delivered inside the building about a week before starting to lay the flooring.

30. Floor joists. - Floor joists should be of thoroughly air- or kilndried lumber and spaced not more than 16 inches, center to center, for subfloor construction.

31. Oak flooring laid on open joists.-When there is no subfloor, oak flooring of $25 / 32$-inch thickness is to be laid directly on the floor 
joists, spaced 12 inches, center to center. Joists should be crossbridged for added rigidity.

32. Subfloor construction-underfloors.-A subfloor is the foundation of the finished floor.

33. In new buildings, it is presumed there will be an underfloor, or subfloor, laid over the joists. A subfloor must be provided in all cases where the oak flooring is of less than $25 / 32$-inch thickness. It is a permanent advantage to have oak floors laid over a subfloor.

34. Subflooring should be 1 - by 4 -inch or 1 - by 6 -inch stock, sized, No. 1 Common or No. 2 Common grade, of good, new, kiln-dried lumber, laid diagonally (at $45^{\circ}$ ) to the joists. The boards should be driven close, but not tight.

35. The subfloor boards should be square-edged, not tongued and grooved or shiplapped, and not wider than 6 inches, and should be clean and straight. Avoid boards that have been used as forms for concrete work.

36. Nailing the subfloors.-Boards must be nailed down solid at every bearing with two 10 -penny nails. All butt joints must rest on bearings. If it is absolutely necessary to use subfloor boards wider than 6 inches, extra nailing must be employed.

37. One of the secrets of obtaining a solid, nonsqueaking, almost "one-piece" oak floor, is to use plenty of nails in both the subfloor and the top floor. See nail schedule, table 5, page 9.

38. Conditioning subfloor surface.-Examine the subfloor carefully. Remove all dirt and plaster lumps, drive down any raised nails, replace broken boards, and make sure the floor is level and solid. Then sweep clean. Use no water.

39. Building paper and insulation.-Lay a good quality building paper over the clean subfloor. Use building paper of a type known as "15-lb asphalt-saturated roll felt." Do not use thin, black-sized or red rosin-sized paper, or slaters' felt.

40. Insulating over heating plant.-For rooms directly over heating plants, use double-weight building paper (30-lb asphalt felt) or 30-lb asbestos paper, or standard insulating board about $1 / 2$ inch thick. If preferred, the insulation can be applied (in new or old buildings) on the basement ceiling, set in between the floor joists.

41. Sleepers, or screeds.-If the underfloor or subfloor is to be omitted and the oak flooring is to be nailed directly to wood "sleepers," or "screeds," set in or on the concrete slab, the sleepers should be spaced not more than 12 inches, center to center.

42. When a subfloor is to be installed over a concrete slab, the sleepers may then be spaced on 16- or 18-inch centers. Sleepers should be tightened in place. For this purpose there are various approved devices such as galvanized metal clips, expansion bolts in lead sleeves, and wire. Fastening and tightening by twisting strong: wire around sleepers has proved a simple and effective method.

43. Preserved lumber for sleepers.-Sleepers should be of pretreated lumber, impregnated with an approved wood preservative. They should be of a lumber grade equivalent to No. 1 Common, 2 by 4 inches or 2 by 3 inches, and laid with the flat side down.

44. Floor furring.-When electrical conduits and piping are to be laid on top of the wood subfloor, floor furring strips of the required thickness, and $1 \frac{3}{4}$ inches wide, are spaced on 10 -inch centers and tacked 
to the subfloor. They are laid at right angles to the direction of the finished flooring. The flooring is nailed through the furring strips, nails one size larger than those specified in the nail schedule, table 5, page 9 , being used.

45. Floor ventilation.-Where basements are not provided, adequate provision must be made for the free movement of cross currents of air beneath the building. This circulation may be obtained by providing vents and other openings in the foundation walls.

46. The total area of vent openings should be at least $1 \frac{1}{2}$ percent of the first-floor area, and more if possible.

47. Stagnant and humid air under a building will encourage stain and decay. The preventive is air circulation. When conditions do not permit adequate ventilation, the oak flooring should never be less than standard ${ }^{25} / 32$-inch thickness. Architectural designs requiring "low-slung" floors may be modified slightly to permit the introduction of sufficient ventilation openings.

\section{NAILS AND NAILING}

48. Proper nails and correct nailing hold the flooring in place, make the floor rigid, and prevent squeaks. The nails should be started through the strip where the tongue leaves the shoulder, and driven inwardly at an angle of $45^{\circ}$ to $50^{\circ}$ to the floor. (See fig. 4.) Countersink all nails with a steel set or use a nail for setting. Do not attempt to do this with a hatchet or hammer, as this may cause bruises and scars that cannot be removed by scraping and sanding.

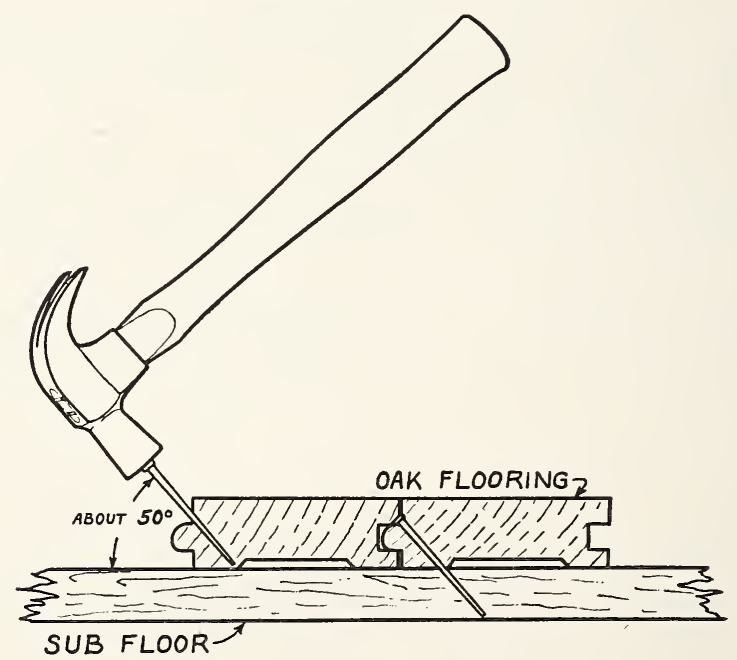

FIgURE 4. Method of nailing. 
TABLE 5. Nail schedule

All tongued-and-grooved oak flooring must be blind-nailed.

All oak flooring $1 / 2$ inch or less in thickness must be laid on a subfloor.

All square-edged flooring must be face-nailed (through the top face) instead of blind-nailed.

\begin{tabular}{|c|c|c|}
\hline \multirow{2}{*}{ Flooring dimensions (inches) } & \multicolumn{2}{|l|}{ Nails } \\
\hline & Size & Spacing \\
\hline $\begin{array}{l}25 / 32 \text { by } 2,21 / 2 \text {, and } 31 / 4 \text { (tongued and } \\
\text { grooved). } \\
25 / 32 \text { by } 11 / 2 \text { (tongued and grooved) } \\
15 / 32 \text { by } 11 / 2 \text {, and } 2 \text { (tongued and } \\
\text { grooved). } \\
11 / 32 \text { by } 11 / 2 \text {, and } 2 \text { (tongued and } \\
\text { grooved). } \\
5 / 16 \text { by } 11 / 2 \text {, and } 2 \text { (square-edged) ..... }\end{array}$ & $\begin{array}{l}\text { 8d light flooring nail-wire or steel-cut } \\
\text { casing nail (cut nail is preferable). } \\
\text { Same as above } \\
6 \mathrm{~d} \text { bright wire casing nails..... } \\
4 \mathrm{~d} \text { bright wire casing nails........... } \\
11 / 8 \text { inch barbed-wire flooring brad, } \\
\text { No. 16; heads countersunk and put- } \\
\text { tied. }\end{array}$ & $\begin{array}{l}10 \text { inches apart. } \\
12 \text { inches apart. } \\
10 \text { inches apart. } \\
8 \text { inches apart. } \\
2 \text { nails every } 7 \text { inches. }\end{array}$ \\
\hline
\end{tabular}

\section{HOW TO LAY OAK FLOORING}

49. The following instructions are intended for the laying of oak floors in new construction and over wood subfloors. However, they also apply generally to the laying of oak flooring over old floors.

50. Where to begin.-Leave an expansion space of not less than $1 / 2$ inch on all sides next to the walls, but not wider than will be covered by the base-shoe, quarter-round, or door thresholds or saddles.

51. The flooring strips are to be started square with the room, against either sidewall. These first strips are to be face-nailed along the edges next to the wall where the base-shoe will conceal the nailing. All other flooring strips are blind-nailed on the tongued edge, except square-edged flooring.

52. Drawing up.-After laying and nailing three or four strips of oak flooring, place a short piece of straight-edged hardwood against the tongue of the outside strip of flooring, and drive it up snugly. This drives the flooring strips into their final position.

53. Flush floor. - Whenever possible, carry the laying through doorways continuously from one room into another, so that all rooms will have a flush floor. Avoid laying a ripped strip at doors or where it may mar the appearance.

54. Joints. -All pieces of flooring strips are tongued and grooved on the sides and on the ends. This is called "side and end matching." The fit of all pieces is practically perfect when laid side to side and end to end. The end jointing, therefore, may come anywhere in the floor, without regard to a joist or a sleeper bearing at the joint; but joints should be placed so as to avoid having two or three ends in line or clustered together.

55. Random laying. - Oak flooring of $25 / 32$ inch thickness is made in widths of $1 \frac{1}{2}$ and $2 \frac{1}{4}$ inches, and also $3 \frac{1}{4}$ inches when ordered. Specify the width desired, or call for all three widths - about an equal quantity of each - to be laid at random. This makes a very interesting floor with a mellowed effect, and is suited to all but the most formal styles of design.

56. Laying new oak floors over old floors.-The old floors serve as subfloors. Replace boards that cannot be planed or nailed down level, drive down all loose nails, nail the boards securely, and make 
sure the old floor is level and free of humps. Remove the base-shoe, or molding strip, at the bottom of the base (baseboard). Sweep clean, and lay saturated felt. Then proceed with the laying of the new oak floor, laying it at right angles to the old floor.

57. Surfacing (scraping or sanding).-Oak flooring is delivered to the job with a wearing surface that is beautifully smooth and as perfect as modern machinery can make it.

58. When ready for surfacing, the floor should be swept clean. Floors should be traversed several times, working on the first traverse across the grain and then lengthwise with the grain, starting with No. 2 sandpaper on the machine and graduating to No. $1 / 2$ sandpaper, on the second traverse, and with No. 0 or No. 00 sandpaper on the third and fourth traverses. For very fine floors, four or five traverses are essential. The floor should then receive a final buffing or cleaning with fine sandpaper (No. 1/2 fine sandpaper that has been used on the machine sander) or No. 0 steel wool-by machine or by hand. Steel wool should not be used, however, just before or after a paste filler is applied.

59. After the floor has been sanded it should be swept perfectly clean, and no one permitted to walk on it until the floor stain, filler, or first coat of finish has been applied and is dry.

60. Finishing.-The finish of oak floors is of vital importance in achieving complete floor satisfaction. Modern floor finishes by many well-known producers are available. For complete information on floor finishes to suit individual tastes, the manufacturers of these products should be consulted.

\section{EFFECTIVE DATE}

61. Having been passed through the regular procedure of the Commodity Standards Division, and approved by the acceptors hereinafter listed, this commercial standard was issued by the United States Department of Commerce, effective from February 25, 1949.

\section{EDWIN W. ELY, \\ Chief, Commodity Standards Division.}

\section{HISTORY OF PROJECT}

On December 12, 1935, the National Oak Flooring Manufacturers' Association requested the cooperation of the Division of Trade Standards (now Commodity Standards Division) in bringing together all interested parties for the development and establishment of a commercial standard for oak flooring. Since members of the Association represented a large percentage of the production volume of oak flooring, the preliminary draft of the standard was based upon requirements contained in the Association's grading rules. The proposed standard was circulated to the trade for acceptance on December 14, 1935.

Upon receipt of official acceptances estimated to represent a satisfactory majority of the production volume, an announcement of promulgation of the standard was issued on February 14, 1936. Designated as CS56-36, the standard was made effective for new production from March 15, 1936. 


\section{FIRST REVISION}

In 1940 the supply of printed copies of this standard became exhausted and a revision of the standard was undertaken to bring it up to date. The major improvement consisted in listing the flooring by actual thicknesses instead of by nominal thicknesses. Upon approval by the standing committee, this revision was circulated on September 16,1940 , for acceptance. In view of the favorable response to this circularization from manufacturers, distributors, arehitects, and users, the success of the revision was announced on January 2, 1941. The revised standard, designated CS56-41, became effective February $1,1941$.

\section{SECOND REVISION}

At the suggestion of the National Oak Flooring Manufacturers' Association, and with the endorsement of the standing committee, a recommended revision of Commercial Standard CS56-41 was submitted on September 30, 1948, to the trade for consideration. The major change effected by this revision was a slight reduction in the average lengths of the flooring, to permit a better utilization of the material now available. However, no change was made in the defects permitted in the various grades.

On January 26, 1949, it was announced that the recommended revision had been accepted by a sufficient number of manufacturers, distributors, and users to warrant its promulgation and publication as Commercial Standard CS56-49.

\section{STANDING COMMITTEE}

The following individuals comprise the membership of the standing committee, which is to review, prior to circulation for acceptance, revisions proposed to keep the standard abreast of progress. Each organization nominated its own representative. Comment concerning the standard and suggestions for revision may be addressed to any member of the committee or to the Commodity Standards Division, National Bureau of Standards, which acts as secretary for the committee.

\section{Manufacturers:}

B. A. Mayhew (chairman), Fordyce Lumber Co., Fordyce, Ark.

W. J. Wright, M. B. Farrin Lumber Co., Winton Place Station, Cincinnati, Ohio.

V. A. Sells, Long-Bell Lumber Co., 926 Grand Ave., Kansas City, Mo. Distributors:

Fred A. Holbrook, Holbrook Lumber Co., Springfield, Mass. (Representing National-American Wholesale Lumber Association.)

Fred R. Stair, Farragut Lumber Co., Inc., 1350 No. Sixth Ave., Knoxville, Users:

Tenn. (Representing National Retail Lumber Dealers Association.)

Theodore I. Coe, Department of Education and Research, American Institute of Architects, 1741 New York Ave., NW., Washington, D. C.

C. O. Christenson, Property Requirements Section, Federal Housing Administration, Washington 25, D. C. 



\section{ACCEPTANCE OF COMMERCIAL STANDARD}

If acceptance has not previously been filed, this sheet properly filled in, signed, and returned will provide for the recording of your organization as an acceptor of this commercial standard.

\section{Date}

Commodity Standards Division,

National Bureau of Standards,

Washington $25, \mathrm{D}$. C.

Gentlemen:

We believe that the Commercial Standard CS56-49 constitutes a useful standard of practice, and we individually plan to utilize it as far as practicable in the

$$
\text { production }^{1} \quad \text { distribution }^{1} \quad \text { purchase }^{1}
$$

of oak flooring. We reserve the right to depart from it as we deem advisable.

We understand, of course, that only those articles which actually comply with the standard in all respects can be identified or labeled as conforming thereto.

Signature of authorized officer

(In ink)

(Kindly typewrite or print the following lines)

Name and title of above officer

Organization

(Fill in exactly as it should be listed)

Street address

City, zone, and State

1 Underscore which one. Please see that separate acceptances are filed for all subsidiary companies and affiliates which should be listed separately as acceptors. In the case of related interests, trade associations, trade papers, etc., desiring to record their general support, the words "General Support" should be added after the signature. 


\section{TO THE ACCEPTOR}

The following statements answer the usual questions arising in connection with the acceptance and its significance:

1. Enforcement.-Commercial standards are commodity specifications voluntarily established by mutual consent of those concerned. They present a common basis of understanding between the producer, distributor, and consumer and should not be confused with any plan of governmental regulation or control. The United States Department of Commerce has no regulatory power in the enforcement of their provisions, but since they represent the will of the interested groups as a whole, their provisions through usage soon become established as trade customs, and are made effective through incorporation into sales contracts by means of labels, invoices, and the like.

2. The acceptor's responsibility.-The purpose of commercial standards is to establish for specific commodities, nationally recognized grades or consumer criteria and the benefits therefrom will be measurable in direct proportion to their general recognition and actual use. Instances will occur when it may be necessary to deviate from the standard and the signing of an acceptance does not preclude such departures; however, such signature indicates an intention to follow the commercial standard where practicable, in the production, distribution, or consumption of the article in question.

3. The Department's responsibility.-The major function performed by the Department of Commerce in the voluntary establishment of commercial standards on a Nation-wide basis is fourfold: first, to act as an unbiased coordinator to bring all interested parties together for the mutually satisfactory adjustment of trade standards; second, to supply such assistance and advice as past experience with similar programs may suggest; third, to canvass and record the extent of acceptance and adherence to the standard on the part of producers, distributors, and users; and fourth, after acceptance, to publish and promulgate the standard for the information and guidance of buyers and sellers of the commodity.

4. Announcement and promulgation.-When the standard has been endorsed by a satisfactory majority of production or consumption in the absence of active valid opposition, the success of the project is announced. If, however, in the opinion of the standing committee or the Department of Commerce, the support of any standard is inadequate, the right is reserved to withhold promulgation and publication. 


\section{ACCEPTORS}

The organizations and individuals listed below have individually accepted this standard for use as far as practicable in the production, distribution, or purchase of oak flooring. In accepting the standard they reserved the right to depart therefrom as they individually deem advisable. It is expected that articles which actually comply with the requirements of this standard in all respects will be regularly identified or labeled as conforming thereto, and that purchasers will require such specific evidence of conformity.

\section{ASSOCIATIONS}

(General Support)

Greater New York Lumber Industries, Inc., New York, N. Y.

National Hardwood Lumber Association, Chicago, Ill.

National Lumber Exporters Association, Memphis, Tenn.

National Oak Flooring Manufacturers Association, Memphis, Tenn.

Prefabricated Home Manufacturers' Institute, Washington, D.C.

Southern Hardwood Producers, Inc., Memphis, Tenn.

\section{FIRMS AND OTHER INTERESTS}

Adams, Franklin O., Tampa, Fla.

Adams, R. T., Co., Boston, Mass.

Admiral Homes, Inc., West Newton, $\mathrm{Pa}$.

Aladdin Co., The, Bay City, Mich.

Anderson-Tully Co., Memphis, Tenn.

Andrews, Jones, Biscoe \& Goodell, Boston, Mass.

Appalachian Oak Flooring \& Hardwood Corp.

Ellijay, Ga.

Arkansas Oak Flooring Co., Pine Bluff, Ark.

Arkansas Valley Lumber Co., Wichita, Kans.

Arrington Lumber Co., Norfolk, Va.

Ashton, Evans \& Brazier, Salt Lake City, Utah.

Atlanta Oak Flooring Co., Atlanta, Ga.

Atlas Manufacturing Co., Castle Shannon, $\mathrm{Pa}$

Bagnal-Nettles Builders Supply Co., Inc., Columbia, S. C.

Baldridge, J. C., Lumber Co., Albuquerque, N. Mex.

Baltimore, City of, Bureau of Building Construction, Baltimore, Md.

Barger, P. M., Lumber Co., Inc., Statesville, N. C.

Barnes Lumber Corp., Charlottesville, Va.

Barnes, W. F. \& J. F., Lumber Co., Waco, Tex.

Barthmaier, Eugene V., Philadelphia, Pa.

Baxter, C. B., \& Co., Kansas City, Mo.

Bearden Lumber Co., Bearden, Ark.

Belli, Edo J., Chicago, Ill.

Binda, Bial \& Gerhardt, Union City, N. J.

Blackburn, Robert, Inc., Milwaukee, Wis.

Botsford Lumber Co., Winona, Minn.

Bradley Lumber Co. of Arkansas, Warren, Ark.

Bruce, E. L., Co., Memphis, Tenn.

Brust \& Brust, Milwaukee, Wis.

Buffalo, City of, Architectural Service, Division of Buildings, Department of Public Works, Buffalo, N. Y.

Burck Construction Co., Hollywood, Calif.

Burritt, A. W., Co., The, Bridgeport, Conn.

Burruss Land \& Lumber Co., Lynchburg, Va.

Burton-Lingo Co., Fort Worth, Tex.

Byers Lumber Co., Hastings, Nebr.

Calcasieu Lumber Co.. Austin. Tex.

Camlet, J. Thomas, Passaic, N. J.

Campbellsville Lumber Co., The, Campbellsville, Ky.

Cannon \& Mullen, Salt Lake City, Utah. Carpenter Oak Flooring Co., Birmingham, Ala.

Carr Lumber Co., Pisgah Forest, N. C.

Cellarius, Chas. F., Cincinnati, Ohio.

Center State Industries, Inc., Wisconsin Dells, Wis.
Central Wholesale Lumber Co., Minneapolis, Minn. Chapin Lumber Co., The, Aurora, Colo.

Chapman \& Dewey Lumber Co., Memphis, Tenn. Charlottesville Lumber Co., Inc., Charlottesville, Va.

Cherokee Flooring Corp., Burlington, N. C.

Chickamauga Cedar Co., Inc., Stevenson, Ala.

Clark Warmington Associates, Inc., Minneapolis, Minn.

Cleverdon, Varney \& Pike, Boston, Mass.

Colonial Hardwood Flooring Co., Inc., Hagerstown Md.

Conrad \& Cummings, Binghamton, N. Y.

Cook, A. B., Co., Ine., Malvern, Ark.

Cookeville Planing Mills, Cookeville, Tenn

Coolidge, Shepley, Bulfinch \& Abbott, Boston, Mass.

Cotton-Hanlon, Inc., Odessa, N. Y.

Cram \& Ferguson, Boston, Mass.

Crossett Lumber Co., Crossett, Ark.

Crowell \& Lancaster, Bangor, Maine.

Dailey Flooring Corp., Dailey, W. Va.

De Soto Hardwood Flooring Co., Memphis, Tenn.

Detroit, City of, City Engineer's Office, Detroit, Mich.

Dickerson Lumber Co., Huntington, W. Va.

Dickey, C. W., Associates, Honolulu, T. H.

Dierks Lumber \& Coal Co., Kansas City, Mo.

Dix Lumber Co., North Cambridge, Mass.

Dixon Lumber Co., Galax, Va.

Empire Millwork Corp., Corona, N. Y.

Everett, H. F., \& Associates, Allentown, Pa.

Fair, D. L., Lumber Co., Louisville, Miss.

Farragut Lumber Co., Knoxville, Tenn

Farris Hardwood Lumber Co., Nashville, Tenn.

Ferguson, W. T., Lumber Co., St. Louis, Mo.

Fitzpatrick, J. J., Lumber Co., Inc., Madison, Wis.

Flannagan, Eric G., Henderson, N.'C.

Florida, University of, School of Forestry, Gainesville, Fla.

Ford, Ivon R., Ine., MeDonough, N. Y.

Fordyce Lumber Co., Fordyce, Ark.

Fort Wayne Builders Supply Co., Fort Wayne, Ind. Frank, Ira, New York, N. Y.

Frost Hardwood Floors, Inc., Shreveport, La.

Galloway Lumber Co., Clarksville, Ark.

General Industries, Inc., Fort Wayne, Ind.

General Millwork Corp., Utica, N. Y.

Gennett Oak Flooring Co., Inc., Asheville, N. C.

Gittings Lumber Co., The, Denver, Colo.

Green Lumber Co., The, Laurel. Miss.

Griffith, Geo. C., Stave Co., Springfield, Mo.

Gurdon Lumber Co., Gurdon, Ark.

Hager \& Cove Lumber Co., Lansing, Mich.

Hahn, Stanley W., Chicago, 111.

Hall, Border \& Donaldson, Baltimore, Md

Hallack \& Howard Lumber Co., The, Denver, Colo.

Hallett Manufacturing Co., Inc., Mobile, Ala.

Haralson \& Mott, Fort Smith, Ark.

Harbaugh, Charles, Lumber Co., Twin Lakes, Wis.

Hardwood Products, Inc., Bluefield, W. Va.

Harris Flooring Co., Long Island City, N. Y.

Harris Hardwood Co., Inc., Roanoke, Va.

Harris Manufacturing Co., Johnson City, Tenn.

Haslam Lumber Co., Haslam, Tex.

Hassell \& Parkes, Iron City, Tenn.

Hawkins Lumber \& Warehouse Co., Boston, Mass.

Hazlewood Co., The, Hazlehurst, Miss.

Higgins, Charles H., New York, N. Y. 
Hightower Box \& Tank Co., Birmingham, Ala.

Hoener, P. John, St. Louis, Mo.

Holbrook Lumber Co., Springfield, Mass.

Folsman, Holsman, Klekamp \& Taylor, Chicago, Ill.

Holt Hardwood Co., Oconto, Wis.

Hope Flooring \& Lumber Co., Hope, Ark.

Hunting, R. D., Lumber Co., Cedar Rapids, Iowa.

Hutton \& Bourbonnais Co., Hickory, N. C.

Inland Floor Co., San Francisco, Calif.

James Lumber Co., Boston, Mass.

Jones, Alf, Lumber Co., Kansas City, Mo.

Kansas State College, Department of Architecture, Manhattan, Kans.

Kellogg Lumber Co., Inc., Monroe, La.

Kennedy Lumber Co., Trenton, N. J.

Lambert Lumber Co., Leavenworth, Kans.

Lancaster Corp., Fort Worth, Tex.

Lanham Hardwood Flooring Co., Louisville, Ky.

Latenser, John, \& Sons, Omaha, Nebr.

Law, Law, Potter \& Nystrom, Madison, Wis.

Leathers, A. H., Manufacturing Co., Dickson, Tenn.

Lester Lumber Co., Inc., Martinsville, Va.

Levy, Will, St. Louis, Mo.

Lightsey Bros., Miley, S. C.

Locb, Laurence M., White Plains, N. Y.

Long-Bell Lumber Co., The, Kansas City, Mo.

Lord \& Bushnell Lumber Co., Chicago, Ill.

Louisiana Central Lumber Co., Clarks, La.

Lucht \& Eckerle, West Englewood, N. J.

Lumber \& Millwork Co. of Philadelphia, The, Philadelphia, Pa.

Lyman-Hawkins Lumber Co., The, Akron, Ohio.

Maisler Bros., Fresno, Calif.

Markland, M. B., Contracting Co., Atlantic City, N. J.

Marsh Lumber Co., Inc., Dover, Ohio. (General support.)

Marshall Wright Lumber Co., Ionia, Mich.

Mason Lumber Co., Jacksonville, Fla.

Mauk, C. A., Lumber Co., The, Toledo, Ohio.

$\mathrm{MeF}$ arland Lumber Co., Norristown, $\mathrm{Pa}$.

MeMahan, M. B., \& Co., Sevierville, Tenn.

Meadow River Lumber Co., The, Rainelle, W. Va.

Memphis Hardwood Flooring Co., Memphis, Tenn.

Meriden Lumber Co., Meriden, Conn.

Merit Oak Flooring Co., Birmingham, Ala.

Michey's Lumber, Inc., Warren, Ark.

Midwest Lumber Co., Dubuque, Iowa.

Miller Bros. Co., Johnson City, Tenn.

Miller \& Co., Selma, Ala.

Miller \& Vrydagh, Terre Haute, Ind.

Missouri Hardwood Flooring Co., Inc., St. Louis, Mo.

Mobile River Saw Mill Co., Mt. Vernon, Ala.

Montgomery Hardwood Flooring Co., Montgomery, Ala.

Montgomery Ward, Chicago, Ill.

Moore \& Co., Le Mars, Iowa.

Moore, L. A., Lumber Co., Mason City, Iowa.

Mooser, William, San Francisco, Calif.

Morrison-Merrill \& Co., Salt Lake City, Utah.

Moscow Lumber Industries Co., Inc., Moscow, Pa.

Mower Lumber Co., The, Charleston, and Cass, W. Va.

Muhlenberg Bros., Reading, $\mathrm{Pa}$.

National Lumber Co., Buffalo, N. $\because$.

Natwick, J., \& Co., Baltimore, Md.

Nickey Bros., Inc., Memphis, Tenn.

North Branch Flooring Co., Chicago, Ill.

North Memphis Lumber Co., Inc., Memphis, Tenn. O \& N Lumber Co., Menomonie, Wis.

Oklahoma, University of, School of Architecture, Norman, Okla.

Oregon, University of, School of Architecture, Eugene, Oreg.

Owen, R. C., Co., Hopkinsville, Ky.

Ozark Oak Flooring Co., Bismarck, Mo.

Paterson-McInnis Lumber Co., Gulf Hammock, Fla.

Pease Woodwork Co., Inc., Cincinnati, Ohio

Peerless Flooring Co., High Point, N. C.

Peerless Housing Co., Inc., New York, N. Y.

Phillips Wood Products Co., Memphis, Tenn. (General support.)

Plunkett-Webster Lumber Co., Inc., New Rochelle, N. Y.
Portsmouth Lumber Corp., Portsmouth, Va.

Prairie du Rocher Lumber Co., Prairie du Rocher, Ill

Rex Mills, Inc., Graceville, Fla.

Rice \& Lockwood Lumber Co., Springfield, Mass. Ripley-Hopping, Inc., Newark, N. J.

Ritter, W. M., Lumber Co., Columbus, Ohio.

Robert \& Co., Inc., Atlanta, Ga

Rose, D. M., \& Co., Knoxville, Tenn.

Ruggles, Carlos, Lumber Co., Springfield, Mass.

Russell, Crowell, Mullgardt \& Schwarz, St. Louis, Mo.

St. Louis, City of, Board of Education, St. Louis, Mo.

Saloy, William, Inc., Jamaica, N. Y.

Schaeffer, Hooten \& Wilson, Bloomington, Ill.

Schmit, Garden \& Erikson, Chicago, Ill.

Schoefield, George M., Nyack, N. Y.

Scottdale IVood Products, Inc., Scottdale, $\mathrm{Pa}$.

Sears, Roebuck \& Co., Chicago, Ill.

Sells Lumber \& Manufacturing Co., Johnson City, Tenn.

Seyler Lumber Co., Bluefield, W. Va.

Shaver, Charles W. \& John A., Salina, Kans.

Shenk, Henry, Co., Erie ,Pa.

Sirrine, J. E., Co., Greenville, S. C.

Sleeper, Harold R., New York. N. Y.

Smith. W. T., Lumber Co., Chapman, Ala.

Snook-Veith Lumber Co., The, Cincinnati, Ohio.

Southern Lumber Co., Warren, Ark.

Southern Pine Lumber Co., Texarkana, Tex.

Standard Lumber Co., Spokane, Wash.

Standard Lumber \& Supply Co., Fort Wayne, Ind. Staub \& Rather, Houston, Tex.

Stewart, E. A., Lumber Co., Inc., Texarkana, Tex. Stoetzel, Ralph, Chicago, Ill.

Stravs, Carl B., Minneapolis, Minn.

Stuart Lumber Corp., Stuart, Va.

Swan Lake Moulding Co., Klamath Falls, Oreg.

Sweet's Catalog Service, New York, N. Y. (General support.)

Taylor, Ellery Kirke, Haddonfield, N. J.

Temple, Seth J. \& Arthur, Davenport, Iowa.

Tennessee Flooring Co., Knoxville, Tenn.

Texas Technological College, Department of Archt tecture, Lubbock, Tex.

Tibbals Flooring Co., Oneida, Tenn.

Tucker, C. M., Lumber Corp., Pageland, S. C

Twin City Hardwood Lumber Co., St. Paul, Minn.

Urania Lumber Co., Ltd., The, Urania, La.

Veach-May-Wilson, Inc., Alcoa, Tenn.

Velde Lumber Co., Pekin, Ill.

Vestal Lumber \& Manufacturing Co., Inc., Knoxville, Tenn.

Vircinia Oak Flooring Co., Inc., Pulaski, Va.

Virginia Polytechnic Institute, Blacksburg, Va. (General support.)

Walsh, Louis A., Waterbury, Conn.

Warr-Caston Lumber Co., Minden, La.

Weinel, Aug. E., Lumber Co., Columbia, Ill.

Welch, Carroll E., Huntington, L. I., N. Y.

Wells, J. W., Lumber Co.. Menominee, Mich.

West, Albert E., Boston, Mass.

West Lumber Co., Atlanta, Ga.

Whissel, L. N., Lumber Co., Inc., Buffalo, N. Y.

Wight \& Wight, Kansas City, Mo.

Willatsen, Andrew, Seattle, Wash.

Williams, J. L., \& Sons, Sheridan, Ark.

Wisconsin's Transfer Yard, Oshkosh, W is.

Wood-Mosaic Co., Louisville, Ky.

Woodstock Lumber Co., Boston, Mass.

Yates-American Machine Co., Beloit, Wis.

Yates, John B., Co., Pennsboro, W. Va.

Zimmerman, A. C., Los Angeles, Calif.

\section{UNITED STATES GOVERNMENT}

Agriculture, U. S. Department of, Forest Service, Procurement \& Supply Division, Missoula, Mont. Army, U. S. Department of the, Standards Branch, Logisties Division, Washington, D. C.

Federal Works Agency, Public Buildings Administration, Washington, D. C. (General support.)

Interior Department, Bureau of Indian Affairs, Washington, D. C.

Justice, U. S. Department of, Bureau of Prisons, Construction Division, Washington, D. C. 


\section{COMMERCIAL STANDARDS}

CS No.

Item

0-40. Commercial standards and their value to business (third edition).

1-42. Clinical thermometers (third edition)

2-30. Mopsticks.

3-40. Stoddard solvent (third edition)

4-29. Staple porcelain (all-clay) plumbing fixtures.

5-46. Pipe nipples, brass, copper, steel, and wrought iron (second edition).

6-31. Wrought-iron pipe nipples (second edition). Superseded by CS5-46.

7-29. Standard weight malleable iron or steel screwed unions.

8-41. Gage blanks (third edition).

9-33. Builders' template hardware (second cdition).

10-29. Brass pipe nipples. Superseded by CS5-46.

11-41. Moisture regains of cotton yarns (second edition).

12-48. Fuel oils (sixth edition).

13-44. Dress patterns (fourth edition).

14-43. Boys' button-on waists, shirts, junior and sport shirts (made from woven fabrics) (third edition)

15-46. Men's pajama sizes (made from woven fabrics) (third edition).

16-29. Wall paper.

17-47. Diamond core drill fittings (fourth edition)

18-29. Hickory golf shafts.

19-32. Foundry patterns of wood (second edition).

20-47. Staple vitreous china plumbing fixtures (fourth edition).

21-39. Interchangeable ground-glass joints, stopcocks, and stoppers (fourth edition).

22-40. Builders' hardware (nontemplate) (second edition).

23-30. Feldspar.

24-43. Screw threads and tap-drill sizes.

25-30. Special screw threads. Superseded by CS24-43.

26-30. Aromatic red cedar closet lining.

27-36. Mirrors (second edition)

28-46. Cotton fabric tents, tarpaulins and covers (second edition).

29-31. Staple seats for water-closet bowls.

30-31. Colors for sanitary ware. (Withdrawn as commercial standard, March $15,1948$.

31-38. Wood shingles (fourth edition)

32-31. Cotton cloth for rubber and pyroxylin coating.

33-43. Knit underwear (exclusive of rayon) (second edition).

34-31. Bag, case, and strap leather.

35-47. Hardwood plywood (third edition)

36-33. Fourdrinier wire cloth (second edition).

37-31. Steel bone plates and screws.

38-32. Hospital rubber sheeting.

39-37. Wool and part wool blankets (second edition). (Withdrawn as commercial standard, July 14, 1941.)

40-32. Surgeons' rubber gloves.

41-32. Surgeons' latex gloves.

42-43. Structural fiber insulating board (third edition).

43-32. Grading of sulphonated oils.

44-32. A pple wraps.

45-48. Douglas fir plywood (eighth edition).

46-40. Hosiery lengths and sizes (third edition).

47-34. Marking of gold-filled and rolled-gold-plate articles other than watcheases.

48-40. Domestic burners for Pennsylvania anthracite (underfeed type) (second edition).

49-34. Chip board, laminated chip board, and miscellaneous boards for bookbinding purposes.

50-34. Binders board for bookbinding and other purposes.

51-35. Marking articles made of silver in combination with gold.

52-35. Mohair pile fabrics (100-percent mohair plain velvet, 100-percent mohair plain frieze, and 50 -percent mohair plain frieze).

53-35. Colors and finishes for cast stone.

54-35. Mattresses for hospitals.

55-35. Mattresses for institutions.
CS No.

Item

56-49. Oak flooring (third edition).

57-40. Book cloths, buckrams, and impregnated fabrics for bookbinding purposes except library bindings (second edition).

58-36. Woven elastic fabrics for use in overalls (overall elastic webbing).

59-44. Textiles-testing and reporting (fourth edition).

60-48. Hardwood dimension lumber (second edition).

61-37. Wood-slat venetian blinds.

62-33. Colors for kitchen accessories.

63-38. Colors for bathroom accessories.

64-37. Walnut veneers.

65-43. Methods of analysis and of reporting fiber composition of textilc products (second edition).

66-38. Marking of articles made wholly or in part of platinum.

67-38. Marking articles made of karat gold.

68-38. Liquid hypochlorite disinfectant, deodorant, and germicide.

69-38. Pine oil disinfectant

70-41. Phenolic disinfectant (emulsifying type) (second edition) (published with CS71-41)

71-41. Phenolic disinfectant (soluble type) (second edition) (published with CS70-41).

72-38. Household insecticide (liquid spray type).

73-48. Old growth Douglas fir, Sitka spruce, and Western hemlock standard stock doors (fourth edition).

74-39. Solid hardwood wall paneling.

75-42. Automatic mechanical draft oil burners designed for domestic installations (second edition).

76-39. Hardwood interior trim and molding.

77-48. Enameled cast-iron plumbing fixtures (second edition).

78-40. Ground-and-polished lenses for sun glasses. (second edition) (published with C S79-40).

79-40. Blown, drawn, and dropped lenses for sun glasses (second edition) (published with CS78-40)

80-41. Electric direction signal systems other than semaphore type for commercial and other vehicles subject to special motor vehicle laws (after market).

81-41. Adverse-weather lamps for vehicles (after market).

82-41. Inner-controlled spotlamps for vehicles (after market).

83-41. Clearance, marker, and identification lamps for vehicles (after market).

84-41. Electric tail lamps for vehicles (after market).

85-41. Electric license-plate lamps for vehicles (after market).

86-41. Electric stop lamps for vehicles (after market).

87-41. Red electric warning lanterns.

88-41. Liquid burning flares.

89-40. Hardwood stair treads and risers.

90- (Reserved for power shovels and cranes).

91-41. Factory-fitted Douglas fir entrance doors.

92-41. Cedar, cypress and redwood tank stock lumber.

93-41. Portable electric drills (exclusive of high frequency).

94-41. Calking lead.

95-41. Lead pipe.

96-41. Lead traps and bends.

97-42. Electric supplementary driving and passing lamps for vehicles (after market).

98-42. Artists' oil paints.

99-42. Gas floor furnaces-gravity circulating type.

100-47. Porcelain-enameled steel utensils (third edition).

101-43. Flue-connected oil-burning space heaters equipped with vaporizing pot-type burners.

102- (Reserved for Diesel and fuel-oil engines).

103-48. Rayon jacquard velour (with or without other decorative yarn) (second edition).

104-46. Warm-air furnaces equipped with vaporizing pot-type oil burners (second edition). 
CS No Item

105-48. Mineral wool insulation for low temperatures (second edition).

106-44. Boys' pajama sizes (woven fabrics) (second edition).

107-45. Commercial electric-refrigeration condensing units (second edition). (Withdrawn as commercial standard September 4, 1947).

108-43. Treading automobile and truck tires.

109-44. Solid-fuel-burning forced-air furnaces.

110-43. Tire repairs - vulcanized (passenger, truck, and bus tires).

111-43. Earthenware (vitreous-glazed) plumbing fixtures.

112-43. Homogeneous fiber wallboard.

113-44. Oil-burning floor furnaces equipped with vaporizing pot-type burners.

114-43. Hospital sheeting for mattress protection.

115-44. Porcelain-enameled tanks for domestic use.

116-44. Bituminized-fiber drain and sewer pipe.

117-44. Mineral wool; blankets, blocks, insulating cement, and pipe insulation for heated industrial equipment.

118-44. Marking of jewelry and novelties of silver.

(E) 119-45.1 Dial indicators (for linear measurements).

120-48. Standard stock ponderosa pine doors (third edition).

121-45. Women's slip sizes (woven fabrics).

122-45. Western hemlock plywood.

123-45. Grading of diamond powder.

(E) 124-45.1 Master disks.

125-47. Prefabricated homes (second edition).

126-45. Tank mounted air compressors.

127-45. Self-contained mechanically refrigerated drinking water coolers.

128-45. Men's sport shirt sizes-woven fabrics (other than those marked with regular neck band sizes).

129-47. Materials for safety wearing apparel (second edition).

130-46. Color materials for art education in schools.
CS No.

Item

131-46. Industrial mineral wool products, all typestesting and reporting.

132-46. Hardware cloth.

133-46. Woven wire netting.

134-46. Cast aluminum cooking utensils (metal composition).

135-46. Men's shirt sizes (exclusive of work shirts).

136-46. Blankets for hospitals (wool, and wool and cotton).

137-46. Size measurements for men's and boys' shorts (woven fabrics).

138-47. Insect wire screening.

139-47. Work gloves.

140-47. Testing and rating convectors.

141-47. Sine bars, blocks, plates, and fixtures.

142-47. Automotive lifts.

143-47. Standard strength and extra strength perforated clay pipe.

144-47. Formed metal porcelain enameled sanitary ware.

145-47. Testing and rating hand-fired hot-watersupply boilers.

146-47. Gowns for hospital patients.

147-47. Colors for molded urea plastics.

148-48. Men's circular flat and rib knit rayon underwear.

149-48. Utility type house dress sizes.

150-48. Hot-rolled rail steel bars (produced from T-section rails).

151-48. Body measurements for the sizing of apparel for infants, babies, toddlers, and children (for the knit-underwear industry).

152-48. Copper naphthenate wood-preservative.

153-48. Body measurements for the sizing of apparel for girls (for the knit-underwear industry). 154- . (Reserved for wire rope).

155-49. Body measurements for the sizing of apparel for boys (for the knit-underwear industry). 156-49. Colors for polystyrene plastics.

157-49. Ponderosa pine and sugar pine plywood.

158-49. Model forms for girls' apparel.

1 Where “(E)" precedes the CS number, it indicates an emergency commercial standard, drafted under war conditions with a view toward early revision.

Notice.-Those interested in commercial standards with a view toward accepting them as a basis of everyday practice may secure copies of the above standards, while the supply lasts, by addressing the Commodity Standards Division, National Bureau of Standards, Washington 25, D. C. 